\title{
Pemanfaatan media pembelajaran berbasis edmodo terhadap motivasi belajar siswa sekolah menengah kejuruan
}

(The impact of electronic media base edmodo on student' motivation learning at vocational high school)

\author{
Try Hikmawan', Alit Sarino ${ }^{2 *}$ \\ 1,2Program Studi Pendidikan Manajemen Perkantoran, \\ Fakultas Pendidikan Ekonomi dan Bisnis, Universitas Pendidikan Indonesia, \\ Jl. Dr. Setiabudhi, No. 229 Bandung, Jawa Barat Indonesia \\ Email : alit@upi.edu
}

\begin{abstract}
ABSTRAK
Motivasi belajar siswa dipengaruhi oleh banyak faktor, diantaranya adalah media pembelajaran. Artikel ini membahas hasil penelitian tentang pengaruh media pembelajaran berbasis edmodo terhadap motivasi belajar pada mata pelajaran simulasi digital di sebuah SMK swasta di Kota Cimahi. Penelitian dilakukan dengan menggunakan metode explanatory survey, dimana data dikumpulkan dengan menggunakan angket model likert yang diberikan kepada sample sejumlah 58 orang siswa kelas X program Administrasi Perkantoran. Hasil penelitian yang dilakukan menunjukkan adanya pengaruh yang positif dan signifikan antara media pembelajaran berbasis edmodo terhadap motivasi belajar siswa baik secara simultan maupun parsial. Artikel ini menekankan pentingnya variabel tersebut dalam usaha meningkatkan motivasi belajar siswa.
\end{abstract}

Kata Kunci : media pembelajaran, edmodo, motivasi belajar

\begin{abstract}
Motivation are influenced by many factors, among others is learning media. This article discusses the findings of research on the impacts of learning media base edmodo on students motivation learning in the subject of office equipment management at a private vocational high school in Cimahi City. The research employed the explanatory survey method, where data were gathered using Likert questionnaire distributed to a sample of 58 tenth grade students of the Office Administration Program. The findings show that learning media base edmodo had positive and significant effects on students motivation learning, both simultaneously and partially. This article emphasizes the importance of both variables in increasing students motivation learning.
\end{abstract}

Keyword : learning media, edmodo, students motivation learning

Received: Agustus 2017, Revision: November 2017, Published: Januari 2018

\footnotetext{
* Corresponding author Copyright (C) 2018, EISSN 2656-4734
} 


\section{PENDAHULUAN}

Perkembangan ilmu pengetahuan dan teknologi yang sangat pesat membuat dunia pendidikan terdorong mengikuti perkembangan. Hal tersebut terbukti dengan pemanfaatan teknologi informasi sebagai media pembelajaran pendamping proses kegiatan belajar dan mengajar di sekolah. Media pembelajaran yang diterapkan di sekolah diharapkan mampu memberikan motivasi kepada siswa untuk aktif dalam kegiatan belajar.

Berbagai macam media pembelajaran yang telah tersedia dan dapat digunakan dalam proses pembelajaran di kelas seperti media audio, media visual, media audio visual dan media serbaneka. Salah satu media pembelajaran yang termasuk ke dalam kategori media visual adalah media pembelajaran elektronik.

Media pembelajaran elektronik merupakan perangkat penting yang dapat digunakan oleh untuk meningkatkannya motivasi dan pendidikan siswa (Mateo, Rey, \& Hernández, 2010). Dalam perkembangannya media pembelajaran elektronik masih sangat jarang digunakan dalam dunia pendidikan sekolah menengah kejuruan, khususnya media pembelajaran elektronik berbasis edmodo.

Edmodo adalah alat media pembelajaran elektronik sederhana yang digunakan untuk menyajikan isi pelajaran, biasanya semua sistem operasi smartphone ini menyediakan alat yang berguna bagi siswa dan guru untuk berinteraksi online di luar kelas dimana saja, kapan saja (Hourdequin, 2014). Media pembelajaran tersebut berbasis website yang mudah untuk digunakan. Hal tersebut karena tampilan dan fitur yang tersedia dalam edmodo mengikuti perkembangan tampilan dari media jejaring sosial yang sering digunakan oleh para siswa.

Fakta tentang rendahnya pemanfaatan media pembelajaran berbasis edmodo berasal dari hasil wawancara dengan guru mata pelajaran produktif di SMK swasta di Kota Cimahi. Rendahnya pemanfaatan media pembelajaran tersebut berdampak pada motivasi belajar siswa yang rendah di sekolah tersebut. Hal tersebut dapat dibuktikan dari data empiris dari sekolah tersebut, yaitu data presensi siswa kelas X pada mata pelajaran produktif selama semester ganjil seperti ditunjukkan pada grafik berikut.

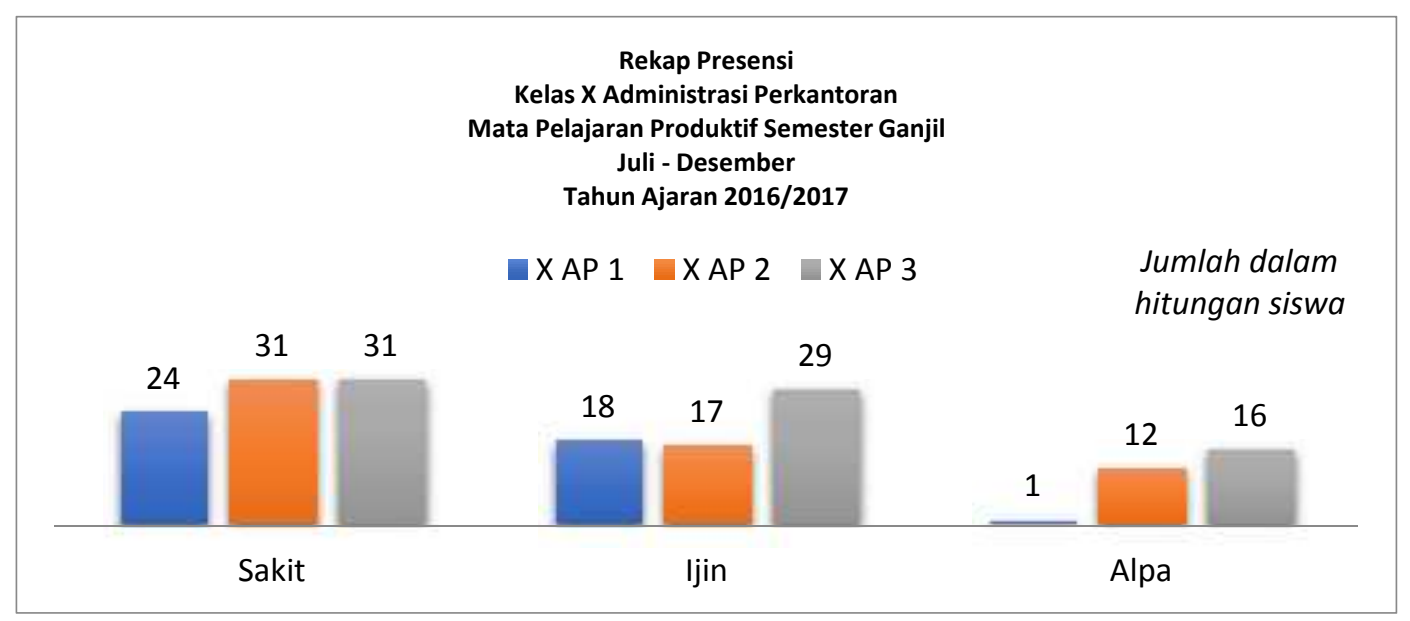

Gambar 1. Rekapitulasi Presensi Siswa

Grafik diatas menggambarkan bahwa selama periode semester ganjil pada mata pelajaran produktif yang didalamnya termasuk mata pelajaran simulasi digital bahwa kehadiran siswa 
cukup rendah kehadirannya, hal tersebut tergambarkan dari jumlah siswa yang sakit, ijin dan alpa. Berdasarkan data-data yang diperoleh, tingginya ketidakhadiran siswa yang tidak hadir dalam kegiatan belajar mengindikasikan minat dan motivasi belajar siswa masih rendah.

Penelitian yang dilakukan oleh (Kim \& Frick, 2011) mengemukakan bahwa hubungan yang signifikan antara e-learning dan motivasi siswa sehingga siswa cenderung lebih termotivasi saat menerapkan e-learning. Jika siswa lebih termotivasi untuk belajar, maka mereka cenderung terlibat; Dan jika mereka terlibat dan terlibat dengan sukses, mereka lebih mungkin untuk mencapai tujuan pembelajaran. Maka dari itu, penulis telah melakukan penelitian yang ditujukan untuk melihat pengaruh minat dan motivasi belajar terhadap hasil belajar siswa di SMK tersebut.

\section{KAJIAN PUSTAKA \\ Media Pembelajaran}

Medium dapat didefinisikan sebagai perantara atau pengantar terjadinya komunikasi dari pengirim menuju penerima (Heinich, Molenda, Russell, \& Smaldino, 2002). Media pembelajaran adalah proses belajar mengajar pada dasamya juga merupakan proses komunikasi, sehingga media yang digunakan dalam pembelajaran (Falahudin, 2014).

Kalau kita amati lebih cermat lagi, pada mulanya media pembelajaran hanyalah dianggap sebagai alat untuk membantu pembelajar dalam kegiatan mengajar (teaching aids). Alat bantu mengajar berikutnya yang digunakan adalah alat bantu visual seperti gambar, model, grafis atau benda nyata lain. Alat-alat bantu itu dimaksudkan untuk memberikan pengalaman lebih konkret, memotivasi serta mempertinggi daya serap dan daya ingat pebelajar dalam belajar (David, 1991).

Pemakaian media pembelajaran dalam proses belajar mengajar dapat membangkitkan minat dan keinginan yang baru, membangkitkan motivasi dan rangsangan kegiatan belajar, dan bahkan membawa pengaruh-pengaruh psikologis terhadap pebelajar. Penggunaan media pembelajaran pada tahap orientasi pengajaran akan sangat membantu keefektifan proses pembelajaran dan penyampaian pesan dan isi pelajaran pada saat itu (Sasonohardjo, 2002). Media pembelajaran elektronik memungkinkan siswa untuk mengoperasikan pembelajaran mereka sendiri sesuai dengan kemampuan mandiri mereka dengan kewenangan untuk memilih sendiri tempat, waktu, konten serta arah penelitian mereka (Rosli, 2016).

\section{Motivasi Belajar}

Motivasi memainkan peran utama dalam karya akademis siswa dan dalam prestasi mereka. Hal ini tercermin dalam tugas yang dikerjakan oleh siswa serta dalam mengatasi hambatan yang mereka hadapi dalam proses belajar (Peklaj, 2006) Menurut (Lee. I, 2010) Motivasi belajar terjadi ketika seseorang mengejar tingkat perkembangan yang lebih tinggi setelah kebutuhan dasar terpenuhi.

Tinggi rendahnya motivasi di tingkat pendidikan berpengaruh pada keberhasilan siswa (Brown, 2001). Kemudian motivasi dapati meningkatkan kinerja pembelajaran hal tersebut memberikan tenaga dan pelajar untuk mencapai tugasnya karena ia memiliki arah dan kinerja pembelajar meningkat (Rehman, 2013).

Dari keseluruhan uraian yang dikemukakan di atas, maka dapat dibuat model kausalitas dan hipotesis penelitian sebagai berikut: 


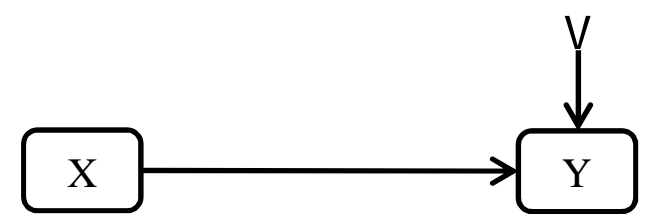

\title{
Gambar 2. Model Hubungan Kausalitas Variabel
}

\author{
Keterangan : \\ X : Variabel Media Pembelajaran Berbasis Edmodo \\ Y : Variabel Motivasi Belajar \\ $\varepsilon \quad$ : Faktor lain yang mempengaruhi $\mathrm{Y}$
}

Hipotesis
$\mathrm{H}_{0}=$ artinya tidak terdapat pengaruh positif antara media pembelajaran berbasis Edmodo dengan motivasi belajar siswa.
$\mathrm{H}_{1}$ = artinya terdapat pengaruh positif antara media pembelajaran berbasis Edmodo dengan motivasi belajar siswa.

\section{METODE PENELITIAN}

Penelitian ini dilakukan untuk mencapai tujuan dari penelitian, yaitu untuk melihat gambaran dan dampak dari pemanfaatan media pembelajaran berbasis edmodo terhadap motivasi belajar siswa. Metode yang digunakan dalam penelitian adalah metode explanatory survey, dengan populasi sebanyak 58 orang siswa kelas X program Administrasi Perkantoran pada mata pelajaran simulasi digital.

Data dikumpulkan menggunakan metode kuesioner dan teknik pengumpulan data melalui penyebaran angket dengan skala likert. Teknik analisis statistik yang digunakan dalam mengolah data adalah teknik analisis deskriptif dan teknik analisis inferensial. Statistik deskriptif digunakan untuk menampilkan gambaran tentang pandangan responden mengenai pemanfaatan media pembelajaran berbasis edmodo dan motivasi belajar yang digambarkan dalam bentuk frekuensi, persentase, dan skor rata-rata. Statistik inferensial digunakan untuk melihat dampak dari minat dan motivasi belajar terhadap hasil belajar serta untuk menguji hipotesis yang diuji menggunakan regresi sederhana, regresi ganda, dan uji hipotesis.

\section{HASIL PENELITIAN DAN PEMBAHASAN Media Pembelajaran Berbasis Edmodo}

Instrumen yang dikembangkan dalam variabel media pembelajaran berbasis edmodo diperoleh dari enam indikator yaitu Guru dan siswa terhubung di dalam dan di luar kelas untuk terjadinya pembelajaran pada Edmodo, Guru dapat mengirimkan materi pembelajaran ke Edmodo dan siswa dapat mengaksesnya yang dapat mempercepat dalam pembelajaran, Menyediakan kemudahan akses yang cepat untuk pembelajaran, ulangan dan informasi akademik pada laman edmodo, Orang tua dapat ikut serta memonitor siswa pada laman Edmodo dalam proses pembelajaran yang dapat memperlancar komunikasi antara guru dan orang tua siswa, Siswa memiliki catatan ketika mengerjakan tugas pada laman Edmodo yang memiliki tenggat waktu dan keterangan lengkap dari yang harus dikerjakan, dan Sesama guru dapat saling 
berinteraksi untuk keperluan pembelajaran seperti materi, ide dan keperluan lainnya di dalam laman Edmodo. Enam indikator tersebut bertujuan untuk mengukur pengaruh media pembelajaran berbasis edmodo terhadap motivasi belajar siswa.

Dari hasil pengolahan data, dapat disimpulkan gambaran tingkat pemanfaatan media pembelajaran berbasis edmodo berada pada kategori sedang/ragu-ragu yang digambarkan melalui frekuensi dan persentase.

Tabel 1.

Gambaran Variabel Pemanfaatan Media Pembelajaran Berbasis Edmodo

\begin{tabular}{|c|c|c|c|}
\hline Alternatif Jawaban & $\begin{array}{c}\text { Interval } \\
\text { Skor }\end{array}$ & Frekuensi & Persentase \\
\hline Tidak Setuju & $1.00-1.82$ & 63 & $8 \%$ \\
\hline Kurang Setuju & $1.83-2.65$ & 213 & $25 \%$ \\
\hline Ragu-Ragu & $2.66-3.48$ & $\mathbf{3 1 7}$ & $\mathbf{3 8 \%}$ \\
\hline Setuju & $3.49-4.31$ & 134 & $16 \%$ \\
\hline Sangat Setuju & $4.32-5.14$ & 113 & $8 \%$ \\
\hline Jumlah & & 63 & \\
\hline
\end{tabular}

Sumber: Data terolah

Untuk melihat gambaran indikator dari variabel minat belajar maka dapat dideskripsikan melalui perhitungan skor rata-rata pada tabel berikut:

Tabel 2.

Gambaran Indikator Media Pembelajaran Berbasis Edmodo dalam Skor Rata-Rata

\begin{tabular}{|l|c|}
\hline \multicolumn{1}{|c|}{ Indikator } & Skor Rata-Rata \\
\hline $\begin{array}{l}\text { Guru dan siswa terhubung di dalam dan di luar kelas untuk } \\
\text { terjadinya pembelajaran pada Edmodo }\end{array}$ & 2,99 \\
\hline $\begin{array}{l}\text { Guru dapat mengirimkan materi pembelajaran ke Edmodo dan } \\
\text { siswa dapat mengaksesnya yang dapat mempercepat dalam } \\
\text { pembelajaran }\end{array}$ & 3,05 \\
\hline $\begin{array}{l}\text { Menyediakan kemudahan akses yang cepat untuk pembelajaran, } \\
\text { ulangan dan informasi akademik pada laman edmodo }\end{array}$ & 2,88 \\
\hline $\begin{array}{l}\text { Orang tua dapat ikut serta memonitor siswa pada laman } \\
\text { Edmodo dalam proses pembelajaran yang dapat memperlancar } \\
\text { komunikasi antara guru dan orang tua siswa }\end{array}$ & $\mathbf{3 , 4 7}$ \\
\hline $\begin{array}{l}\text { Siswa memiliki catatan ketika mengerjakan tugas pada laman } \\
\text { Edmodo yang memiliki tenggat waktu dan keterangan lengkap dari } \\
\text { yang harus dikerjakan }\end{array}$ & 3,22 \\
\hline
\end{tabular}

Sumber: Data terolah

Variabel media pembelajaran berbasis edmodo berada pada kategori sedang/ragu-ragu dengan persentase $38 \%$. Berdasarkan skor rata-rata indikator tertinggi adalah indikator sesama guru dapat saling berinteraksi untuk keperluan pembelajaran seperti materi, ide dan keperluan lainnya di dalam laman Edmodo dengan skor 3,49. Indikator terendah adalah menyediakan 
kemudahan akses yang cepat untuk pembelajaran, ulangan dan informasi akademik pada laman edmodo dengan skor 2,88 .

\section{Motivasi Belajar Siswa}

Deskripsi variabel prestasi belajar kognitif diperoleh melalui perhitungan nilai rata-rata hasil belajar siswa dari tiap kelas pada mata pelajaran produktif. Pada salah satu SMK Swasta di Kota Cimahi, penetapan rata-rata nilai KKM mata pelajaran produktif salah satunya Simulasi Digital yaitu 78. Hasil pengolahan data tersebut, diperoleh rincian seperti yang tertera dalam tabel berikut :

Tabel 3.

Persentase Nilai Simulasi Digital Semester Ganjil Tahun Ajaran 2016-2017 Kelas X Administrasi Perkantoran SMK Sangkuriang 1 Cimahi

\begin{tabular}{|c|c|c|c|}
\hline Rentang & Penafsiran & Jumlah & \% \\
\hline $0-59$ & Sangat Rendah & 16 & $34 \%$ \\
\hline $\mathbf{6 0 - 6 9}$ & Rendah & $\mathbf{2 2}$ & $\mathbf{4 7 \%}$ \\
\hline $70-79$ & Sedang & 5 & $11 \%$ \\
\hline $80-89$ & Tinggi & 4 & $9 \%$ \\
\hline $90-100$ & Sangat Tinggi & 0 & $0 \%$ \\
\hline & Jumlah & 47 & $100 \%$ \\
\hline
\end{tabular}

Sumber: Data Nilai Terlampir

Tabel 3, menunjukan bahwa rata-rata hasil belajar kelas $\mathrm{X}$ pada mata pelajaran simulasi digital terdapat pada rentang $47 \%$ dengan keterangan belum mencapai KKM.

\section{PENGUJIAN HIPOTESIS}

Untuk melihat dampak antara variabel minat belajar terhadap hasil belajar maka dianalisis dengan statistik inferensial menggunakan perhitungan analisis regresi sederhana. Diperoleh persamaan regresi $\hat{Y}=49,0664+0,0777 \mathrm{X}$. Tanda $(+)$ di depan angka 0,7777 menunjukkan hubungan antara variabel bebas (media pembelajaran berbasis edmodo) dan variabel terikat (motivasi belajar) berjalan satu arah. Jika media pembelajaran berbasis edmodo meningkat, maka variabel motivasi belajar siswa juga akan meningkat begitupun sebaliknya.

Berdasarkan perhitungan pengujian hipotesis diperoleh $F_{\text {hitung }}$ sebesar 13,222 dan $F_{\text {tabel }}$ 4,0069 dengan tingkat $\alpha=0,05$ dan $\mathrm{dk}_{\text {regb/a }}=1$ dan $\mathrm{dk}_{\text {res }}=\mathrm{n}-2=60-2=58$, artinya $\mathrm{F}_{\text {hitung }} \Psi_{\text {tabel }}$ yaitu $13,222 \geq 4,0069$. Nilai koefisien determinasi media pembelajaran berbasis edmodo sebesar $18,56 \%$. Artinya, secara simultan media pembelajaran berbasis edmodo memiliki dampak terhadap motivasi belajar siswa sebesar $62,87 \%$. Sisanya sebesar $81,44 \%$ dipengaruhi oleh faktor lain yang mempengaruhi hasil belajar. Dapat disimpulkan bahwa "terdapat pengaruh positif dan signifikan antara media pembelajaran berbasis edmodo terhadap motivasi belajar siswa pada mata pelajaran simulasi digital kelas X Administrasi Perkantoran”.

\section{KESIMPULAN}

Pemanfaatan media pembelajaran berbasis edmodo pada Sekolah Menengah Kejuruan (SMK) Swasta di Kota Cimahi berada pada kategori cukup kuat dalam mempengaruhi motivasi belajar siswa. Indikator media pembelajaran berbasis edmodo meliputi Guru dan siswa 
terhubung di dalam dan di luar kelas untuk terjadinya pembelajaran pada Edmodo, Guru dapat mengirimkan materi pembelajaran ke Edmodo dan siswa dapat mengaksesnya yang dapat mempercepat dalam pembelajaran, Menyediakan kemudahan akses yang cepat untuk pembelajaran, ulangan dan informasi akademik pada laman edmodo, Orang tua dapat ikut serta memonitor siswa pada laman Edmodo dalam proses pembelajaran yang dapat memperlancar komunikasi antara guru dan orang tua siswa, Siswa memiliki catatan ketika mengerjakan tugas pada laman Edmodo yang memiliki tenggat waktu dan keterangan lengkap dari yang harus dikerjakan memiliki tingkat rata-rata dengan kategori "sedang". Sementara itu indikator motivasi belajar siswa yang meliputi Minat dan perhatian siswa terhadap pelajaran, Semangat siswa untuk melakukan tugas-tugas belajarnya, Tanggung jawab siswa dalam mengerjakan tugas-tugas belajarnya, Reaksi yang ditunjukkan siswa terhadap stimulus yang diberikan guru, dan Rasa senang dan puas dalam mengerjakan tugas yang diberikan memiliki tingkat rata-rata dengan kategori "sedang".

Dalam pengaruhnya pemanfaatan media pembelajaran memiliki pengaruh positif yang cukup kuat dan signifikan terhadap motivasi belajar siswa. Hal ini menunjukan bahwa motivasi belajar siswa dapat dipengaruhi oleh media pembelajaran berbasis edmodo. Meskipun pengaruh yang dihasilkan oleh variabel media pembelajaran berbasis edmodo kuat, tetapi variabel ini sangat signifikan dan memilik pengaruh yang timbal balik dalam memberikan pengaruh terhadap motivasi belajar siswa.

\section{DAFTAR PUSTAKA}

Brown, H. (2001). Teaching by Principles An Integrative Approach to Language Pedagogy. New York: White Plains.

David, B. (1991). Teaching with Media, a paper presented at Technology and Education Conference in Athens, Greece. Greece.

Falahudin, I. (2014). Pemanfaatan Media dalam Pembelajaran (Vol. Edisi 1). Jurnal Lingkar Widyaiswara.

Heinich, R., Molenda, M., Russell, J., \& Smaldino, S. (2002). Instructional media and technology for learning, 7th edition. New Jersey: Prentice Hall, Inc.

Hourdequin, P. (2014). Edmodo: A Simple Tool for Blended Learning. The Language Teacher38.

Kim, K., \& Frick, W. (2011). Changes in Student Motivation during Online Learning (Vol. 44). Journal of Educational Computing Research.

Lee. I, C. (2010). The Effect of Learning Motivation, Total Quality Teaching and Peer Assisted Learning on Study Achievement: 56 Empirical Analysis from Vocational Universities or College' students in Taiwan (Vol. 6). The Journal of Himan Resource and Adult Learning.

Mateo, Rey, P. d., \& Hernández. (2010). Student motivation and cross-curricular development through e-learning applied to cooperation. The Future of Global Learning Engineering Education (EDUCON). 
Peklaj, C. L. (2006). Students' motivation and academic success in relation to the quality of individual and collaborative work during a course in educational. Co-operatiPartnerships in Teacher Education Proceedings of the 31st Annual ATEE Conference.

Rehman, A. (2013). The Impact Of Motivation On Learning Of Secondary School Students In (Vol. 2). Karachi: Educational Research International.

Rosli. (2016). E-Learning and Social Media Motivation Factor Model (Vol. 9). Johor Bahru: Canadian Center of Science and Education.

Sasonohardjo, W. \&. (2002). Media Pembelajaran Bahan Ajar Diklat Kewidyaiswaraan Berjenjang Tingkat Pertama. Lembaga Administrasi Negara. 